\title{
The concept of hybridization and its contribution to urban ethnobiology
}

\author{
Ana Haydeé Ladio* and Ulysses Paulino Albuquerque²
}

\begin{abstract}
Both ethnozoological and ethnobotanical studies carried out in cities mention the complexity of these cases and the need for shortcuts to aid understanding of the different social, cultural, economic and ecological processes which interact. In this work we propose and discuss a possible shortcut that could be useful in studies related to urban ethnobiology, the use of the concept of process of hybridization. Particularly, we show in the case of the study of medicinal plant use in cities that the hybridization process can be detected and described in a more complete way if we take into account some sub processes such as: fusion or juxtaposition, re-localization, recombination, restructuring, special segregation, new developments in production, circulation and consumption and simultaneous coexistence of different symbolic universes. We propose that these seven processes could be used as a quali-quantitative check list in future urban ethnobiological studies in order to visualize, contextualize and characterize hybridization more profoundly.
\end{abstract}

Keywords: Medicinal plants, South America, Modernization

\section{INTRODUCTION}

In an attempt to understand relationships between human beings and their biological resources, ethnobiology has drawn on numerous concepts, theories and perspectives from different branches of science as heuristic models (Albuquerque et al. 2014; Ladio and Molares 2014). Something that can be used as a heuristic tool serves as a model to orient interpretation and encourage creativity, and is a shortcut that frequently originates in analogous reasoning and can have great explanatory potential.

The logic that lies behind heuristic models and tools is useful both at the level of individuals' mental processes (Berlin 1992; Casagrande 2002) and group or collective processes, such as those involved in the construction of scientific theories. As a branch of ethnoscience, since it studies other knowledge systems (Costa-Neto et al. 2009), and due to its trans-disciplinary profile (Albuquerque et al. 2014), ethnobiology can be considered an interesting example of integration and assimilation of concepts from 'outside' (from other disciplines and/or cultural domains) which summarize and transmit information and act as shortcuts in their own theoretical structure. In this work we propose and discuss a possible shortcut that could be useful in studies related to urban ethnobiology.

1 INIBIOMA, Instituto de Investigaciones em Biodiversidad y Medio Ambiente, CONICET, Universidad Nacional del Comahue, Quintral 1250, San Carlos de Bariloche, Argentina

* Corresponding author. E-mail adress: AHL (ahladio@gmail.com)

2 Laboratório de Etnobiologia Aplicada e Teórica, Departamento de Biologia, Universidade Federal Rural de Pernambuco, Av. Dom Manoel de Medeiros, s/n, Dois Irmãos, CEP: 52171-900, Recife, PE, Brasil 


\section{Cities and ethnobiology}

One of the most paradigmatic topics within ethnobiology occurs in urban cultural systems in association with the use of biological resources (Balick et al. 2000; CostaNeto et al. 2009; Medeiros et al. 2013; Pochettino et al. 2010). Cities are seen as systems where societies and nature are inseparable, forming a socio-environmentally highly variable ecosystem where natural and artificial elements are mutually interconnected (Duarte Almada 2010). There is no doubt that this scenario stimulates our interest in urban ethnobiology. Just as urban ecology is an emerging field which, amongst other aims, seeks to understand how social and ecological systems are integrated, this new approach focuses on the aspects of this relationship which reflect the conceptions, knowledge and practices in current use.

Both ethnozoological (Alves and Rosa 2012) and ethnobotanical (e. g. Albuquerque et al. 2007; Pieroni et al. 2002) studies carried out in cities mention the complexity of these cases and the need for shortcuts to aid understanding of the different social, cultural, economic and ecological processes which interact. In these systems different symbolic, economic and cultural universes coexist due to national and foreign immigrants who recreate their cultural background as well as they can. There is also a strong mass media presence, and conceptions, contexts and regulations associated with an urban life where, despite everything, primary plant and animal products are still used (Alves and Rosa 2005; Andrade and Costa-neto 2006; Ceuterick et al. 2011; McMillen 2012; Richeri et al. 2010a). In the case of Latin American cities, the logic of globalization and the capitalist market is just as noticeable as in the rest of the world, in terms of what can be described as the effect of 'modernization' (Duarte Almada 2010). In particular, the modernization of agriculture with the Green Revolution in the mid 20th century generated the migration of millions of rural families to Latin American cities in search of new opportunities, since the new production methods held no place for them. In addition to this there was their multi-ethnic character, constructed over a long history of encounters and confrontations (including various instances of genocide) involving the combination of Spanish and Portuguese colonizers, followed by the English and French, with indigenous communities to which was added the slaves brought over from Africa. All this made miscegenation a basic process in these societies, which continue to be enriched through the cultural heritages of others. In other words, the urban enclaves of Latin America today possess the particular characteristic of their multi ethnic origin, which affects, to different extents, modern/market ideas. This context of cultural pluralism in Latin America offers scientists interesting challenges and new research opportunities, principally related to the understanding of how these different cultural backgrounds interact with each other and the role played by socioeconomic drivers. These factors give rise to different scenarios of production and reproduction of knowledge associated with the use of natural resources in cities.

Another characteristic trait is the spatial heterogeneity of cities, due as much to their geomorphological and ecological-environmental structure as to their socially constructed environments. In all Latin American cities there are areas of spontaneous settlement, (known as villas or favelas) which are often situated on the outskirts of cities, and which are inhabited by lowincome families who live alongside other sectors of society. Some of these neighborhoods are characterized by the inclusion of different foreign communities or people with different sociocultural backgrounds. Despite the constant coming and going of people to and from different areas of the city, there are some clearly marked patterns of spatial segregation, forming a complete mosaic presenting varying levels of interaction with wild, cultivated or domesticated natural resources (Cuassolo 2009; Duarte Almada 2010).

For this reason, the use of local primary resources (wild and/or cultivated plants or animals without significant transformations) together with others that come from other regions of the world is a prominent feature in this context. In these cities, diet (Hurrell et al. 2011; Jiang and Quave 2013; Ladio and Lozada 2001; Ladio and Rapoport 1999; Ladio et al. 2013), medicine (Alves and Rosa 
2012; Leitão et al. 2013; Nascimento et al. 2005; Pochettino et al. 2010), hedges (e.g. Rovere et al. 2013), the decoration of homes and gardens (e.g. Drescher et al. 2006; WinklerPrins 2002), the trees growing in public places (Barreiro 2006), as other uses, all involve the employment of different species to satisfy the material and symbolic needs of inhabitants (Ceuterick et al. 2008, 2011; Duarte Almada 2010). The kinds of selection process carried out in cities, and the meanings and transactions involved in the use of a particular primary resource, the exclusion of another, or the replacement of one with another, are the questions we hope to answer in our discipline. In addition to these questions, we ask ourselves how certain resources are incorporated into previous belief systems. What significance do they have in the different experiences of city-dwellers?

Amongst the biological resources most studied in ethnobiology in the cities are medicinal plants. According to numerous urban ethnobiological studies, allopathic and herbal medicine coexist spatially due to the continued use of traditional medicines, home remedies (Cuassolo 2009; Pochettino et al. 2008) and the ever increasing number of inhabitants who follow philosophies which promote the holistic care associated with a New Age cosmovision, using medicinal plants as opposed to allopathy (Pochettino et al. 2012). Furthermore, many low-income sectors in these cities have no alternative, for economic reasons, but to resort to the use of plants (Acosta et al. 2013; Cuassolo 2009). Hence, the repertoire of plants for sale or for domestic use, whether traditional or new arrivals, is both on the increase and changeable. We know very little, for example, of the drivers that can explain the diversity of resources used, or the factors which regulate the incorporation or exclusion of resources from the system.

\section{The process of hybridization in ethnobiology}

A workable model for the study of these systems is the hybridization process as used by social sciences. According to García Canglini's definition (2001), this comes into play when structures or discrete practices that previously existed separately come together to create new structures and practices. From an ethnobiological perspective, this would be when traditional customs, defined in terms of a set of practices and biological resources that are reproduced in a society in the same place over many generations (Ladio and Molares 2014), adjust to modernity, and vice versa.

The concept of this hybridization process implies cultural restructuring which is expressed in different ambits, but especially in the material, economic and symbolic spheres. For example, in this restructuring, traditional herb treatments may not disappear; they may become integrated in new ways, and thus participate in some way in the new urban-commercial circuit (Garcia Canclini 2001). We can therefore say that this concept speaks to us firstly, in a general way, of a dynamic process within which there are patterns that can be observed in space and time. Implicit in this concept is also the idea of heterogeneity.

When we speak of hybridization, we do not refer to the homogenization or mixing of knowledge systems, we mean rather that all these systems coexist in the same space. In Brazil and Argentina the idea of hybrid systems has been discussed in the context of multiculturalism, when for example, a traditional medical system comes into contact with biomedicine. The way that this contact is processed is still the subject of research and reflection (see Soldati and Albuquerque 2012).

This concept (sensu Garcia Canclini 2001) when applied in ethnobiology is of great heuristic value since it possesses a multiple, integrative logic that is very necessary in this discipline, and can act as a theoretical shortcut. It is a process that emerges in multidetermined scenarios where diverse systems intersect and interpenetrate. Although this term has been used for some years in ethnobiology to describe mixed systems (e.g. Cuassolo 2009; Medeiros et al. 2013; Pochettino et al. 2008) up to the present time it has not been used as the focus of more profound reflection. Pieroni et al. (2012) have recently use the term "hybrid ethnobotany" but have not offered a full explanation of its theoretical implications. If we reexamine the concept of hybridization, and break it 
up, we can detect the underlying processes that can characterize it more precisely.

\section{Hybridization, its detectable sub processes and the use of medicinal plants}

In the study of medicinal plant use (whether commercialized or not) in an urban environment, the hybridization process can be detected and described in a more complete way if we take into account the following sub processes (Table 1): 1) Fusion or juxtaposition: when, in the cities, different species and practices are added, increasing the total richness of medicinal plants. 2) Relocalization: when resources and/or practices are reused or practiced in new physical ambits where they had not previously existed. 3) Recombination: when traditional and new elements mix, with the objective of increasing therapeutic action or improving the organoleptic properties of the preparation, without generating replacement. 4) Restructuring: when changes and/or substitution of a resource are generated, due to scarcity or other factors, implying a significant change in the order of importance of the species used to treat a particular illness. 5) Spatial segregation: when internal groupings are formed in terms of species and practices that can be observed spatially, in the urban geography. 6) New developments in production, circulation and consumption of the plants and their associated practices: when there are innovations in local therapies and their forms of acquisition, access and utilization. And 7) Simultaneous coexistence of different symbolic universes: when there is evidence of the coming together of different ways of perceiving health and illness and the different treatment methods of different cultural patrimonies. Table 1 shows the details of some examples of ethnobotanical research based on field work in Latin American urban areas for each of these processes, showing, although not exhaustively, that the processes mentioned above do all exist. If a more complete panorama is required of what happens in cities with regard to medicinal plants, we propose that the seven processes mentioned above be used as a quali-quantitative check list in future urban ethnobiological studies in order to visualize, contextualize and characterize hybridization more fully.

The processes mentioned can be used in research in an attempt to approach and understand hybridization, but should not be taken as an explanation of the phenomena studied. For example, we can observe that fusion or juxtaposition of medicinal plant resources occurs in a given cultural reality, increasing the total richness of available resources. In addition, however, it is necessary to analyze whether all these resources have the same significance and what forces are influential in determining the preferential use of the different items. 
Table 1. Hibridization sub-processes and some examples of medicinal plant research based on field work in Latin American urban areas.

\begin{tabular}{|c|c|c|c|}
\hline $\begin{array}{l}\text { Hibridization } \\
\text { sub-process }\end{array}$ & Process concept & Example found in Latin American cities & References \\
\hline $\begin{array}{l}\text { 1. Fusion and/ } \\
\text { juxtaposition }\end{array}$ & $\begin{array}{c}\text { Species and/or practices are } \\
\text { added }\end{array}$ & $\begin{array}{l}\text { The urban herbolarium grows constantly } \\
\text { with input from native and exotic plants }\end{array}$ & $\begin{array}{l}\text { Acosta et al. 2013; de Albuquerque } \\
\text { et al. 2007; Bussmann et al. 2007; } \\
\text { Cuassolo 2009; Cuassolo et al. 2011; } \\
\text { Hilgert et al. 2010; Hurrell et al. 2011; } \\
\text { Macía et al. 2005; Martínez 2005; } \\
\text { Molares et al. 2012; Vandebroek and } \\
\text { Balick } 2012\end{array}$ \\
\hline \multirow[t]{3}{*}{$\begin{array}{l}\text { 2. Re- } \\
\text { localization }\end{array}$} & \multirow[t]{3}{*}{$\begin{array}{l}\text { Reuse of plants ad practices in } \\
\text { new physical contexts }\end{array}$} & $\begin{array}{l}\text { Traditional ritual plants are also used in } \\
\text { urban environments }\end{array}$ & $\begin{array}{l}\text { Albuquerque et al. 2007; Albuquerque } \\
\text { et al. 2005; Richeri et al. 2010b }\end{array}$ \\
\hline & & $\begin{array}{l}\text { Algae are used as a dietary supplement } \\
\text { and slimming aid/to prevent weight loss } \\
\text { in countries where they are not commonly } \\
\text { consumed. }\end{array}$ & Arenas 2009; Arenas et al. 2013 \\
\hline & & $\begin{array}{l}\text { Immigrants continue to use medicinal } \\
\text { plants from their place of origin. }\end{array}$ & $\begin{array}{l}\text { Arenas et al. 2011; Arenas 2007; } \\
\text { Ceuterick et al. 2008, 2011; Pieroni et } \\
\text { al. 2008; Pochettino et al. 2012; Richeri } \\
\text { et al. 2010b }\end{array}$ \\
\hline \multirow[t]{2}{*}{$\begin{array}{l}3 . \\
\text { Recombination }\end{array}$} & \multirow{2}{*}{$\begin{array}{l}\text { The generation of new recipes } \\
\text { that mix traditional plants } \\
\text { with new resources that } \\
\text { increase the therapeutic effect } \\
\text { or improve the organoleptic } \\
\text { properties of the preparation }\end{array}$} & $\begin{array}{l}\text { Plants of European origin are added to } \\
\text { recipes to improve the flavor of therapeutic } \\
\text { mixtures. }\end{array}$ & $\begin{array}{l}\text { Albuquerque et al. 2007; Cuassolo } \\
\text { 2009; Medeiros et al. } 2012\end{array}$ \\
\hline & & $\begin{array}{l}\text { Amongst immigrants medicinal plants are } \\
\text { mixed with commercial drugs to increase } \\
\text { action. }\end{array}$ & Waldstein 2006 \\
\hline 4. Restructuring & $\begin{array}{l}\text { Changes and/or substitutions } \\
\text { are generated for a herbal } \\
\text { resource, due to scarcity or } \\
\text { other factors that imply a } \\
\text { significant change in the order } \\
\text { of importance of species used } \\
\text { to treat a certain illness. }\end{array}$ & $\begin{array}{l}\text { The medicinal plants used in immigrant } \\
\text { sectors of cities should restructure their } \\
\text { herbolaria. }\end{array}$ & $\begin{array}{l}\text { Ceuterick et al. 2008, 2011; Medeiros } \\
\text { et al. 2012; Richeri et al. 2010a; Volpato } \\
\text { et al. } 2009\end{array}$ \\
\hline \multirow[t]{2}{*}{$\begin{array}{l}\text { 5. Spatial } \\
\text { segregation }\end{array}$} & \multirow{2}{*}{$\begin{array}{l}\text { Internal groupings are formed } \\
\text { in terms of species and } \\
\text { practices that can be observed } \\
\text { in the urban geography }\end{array}$} & $\begin{array}{l}\text { The commercialization of medicinal plants } \\
\text { varies geographically according to sales } \\
\text { outlets. }\end{array}$ & Acosta et al. 2013; Cuassolo 2009 \\
\hline & & $\begin{array}{l}\text { The commercialization of plants is } \\
\text { segregated into specific sales outlets for } \\
\text { different ethnic groups. }\end{array}$ & $\begin{array}{l}\text { Balick et al. 2000; Ceuterick et al. 2008, } \\
\text { 2011; Pochettino et al. 2012; Waldstein } \\
2006\end{array}$ \\
\hline \multirow{8}{*}{$\begin{array}{l}\text { 6. New } \\
\text { developments } \\
\text { in production, } \\
\text { circulation and } \\
\text { consumption }\end{array}$} & \multirow[t]{8}{*}{$\begin{array}{l}\text { Innovations are made in local } \\
\text { therapies and their forms of } \\
\text { acquisition, access and use }\end{array}$} & $\begin{array}{l}\text { The use of traditional plants of symbolic } \\
\text { value is re-invented in the cities, with new } \\
\text { elements and naming systems. }\end{array}$ & $\begin{array}{l}\text { Arenas et al. 2011; Hilgert et al. 2010; } \\
\text { Pirondo et al. 2011; Waldstein } 2006\end{array}$ \\
\hline & & $\begin{array}{l}\text { Gathering in indigenous communities is } \\
\text { re-focused according to market demands. }\end{array}$ & Balick et al. 2000; Martínez et al. 2006 \\
\hline & & $\begin{array}{l}\text { Immigrants cultivate their medicinal and } \\
\text { edible plants in urban vegetable gardens } \\
\text { for family consumption and sale in fairs. }\end{array}$ & $\begin{array}{l}\text { Ceuterick et al. 2008, 2011; Medeiros et } \\
\text { al. 2012; Pochettino et al. 2012; Volpato } \\
\text { et al. } 2009\end{array}$ \\
\hline & & $\begin{array}{l}\text { The use of algae is intensified in cities, as a } \\
\text { slimming aid/to prevent weight loss. }\end{array}$ & $\begin{array}{l}\text { Arenas 2009; Molares et al. 2012; } \\
\text { Pochettino et al. } 2008\end{array}$ \\
\hline & & Native plants are new adaptogens in cities. & $\begin{array}{l}\text { Arenas et al. 2011; Ceuterick et al. } \\
\text { 2008; Hurrell et al. 2013; Pochettino et } \\
\text { al. } 2012\end{array}$ \\
\hline & & $\begin{array}{l}\text { Legal and illegal importation of medicinal } \\
\text { plants and barter enable the use of } \\
\text { important plants in the herbolaria of } \\
\text { immigrants in cities. }\end{array}$ & $\begin{array}{l}\text { Acosta et al. 2013; Balick et al. 2000; } \\
\text { Ceuterick et al. 2008, 2011; Medeiros et } \\
\text { al. 2012; Richeri et al. 2010b; Waldstein } \\
2006\end{array}$ \\
\hline & & $\begin{array}{l}\text { Weeds from suburban vegetable gardens } \\
\text { are sold as medicines in urban fairs. }\end{array}$ & Ladio et al. 2013 \\
\hline & & $\begin{array}{l}\text { Due to the absence of traditional doctors in } \\
\text { cities, naturopathic doctors are consulted. }\end{array}$ & $\begin{array}{l}\text { Cuassolo 2009; Zapata and Shippee- } \\
\text { Rice } 1999\end{array}$ \\
\hline \multirow{2}{*}{$\begin{array}{l}\text { 7. Simultaneous } \\
\text { coexistence } \\
\text { of different } \\
\text { symbolic } \\
\text { universes }\end{array}$} & \multirow{2}{*}{$\begin{array}{l}\text { The coming together of } \\
\text { different ways of perceiving } \\
\text { health and illness and } \\
\text { different treatment methods }\end{array}$} & $\begin{array}{l}\text { Prayers and religious rites accompany the } \\
\text { therapy of immigrants in cities. }\end{array}$ & $\begin{array}{l}\text { Albuquerque et al. 2007; Richeri et al. } \\
\text { 2010b }\end{array}$ \\
\hline & & $\begin{array}{l}\text { Magic and medicinal plants coexist in } \\
\text { cities as identity-defining elements. }\end{array}$ & $\begin{array}{l}\text { Albuquerque et al. 2007; Ceuterick et } \\
\text { al. 2008; Macía et al. 2005; Richeri et } \\
\text { al. } 2010\end{array}$ \\
\hline
\end{tabular}


It is important to point out that the seven hybridization sub-processes indicated do not act independently, but rather interact mutually; at times they can be difficult to separate even though the attempt to categorize them is done with great care. Cultural inertia with regard to the use of certain familiar resources and market pressure through advertising in favor of new resources generate asymmetry in terms of power and prestige, which determines the success of one species over another. Consequently, we can find, for example, cases of successful fusion and incompatible recombination, innovation and/ or fusion. In particular, in the last mentioned case, these are very difficult to detect without a study to identify elements that could not enter the system (even if only temporarily) and this demands comparative studies between pre and post urbanization states. The most concrete case is immigrants' disuse of traditional species in urban contexts which are very different to their original socio-environmental background, with very strict laws on the importation of biological resources being one of several socio-economic factors which lead to certain resources falling into disuse (Medeiros et al. 2012).

It is also necessary to take the ideological and symbolic scenarios underlying the dynamics of the differential use of certain resources into consideration. Soldati and de Albuquerque (2012), while studying the medical system of the Fulni-ô Indians who live in urban areas in the northeast of Brazil, reflected that hybridization is an intermediate position, a contact zone where points of conflict and clashes of interest are evident. Biomedicine represents a colonial project of domination that no longer takes place through economic or territorial conquest but happens through strong influence on local cultures and, especially, through scientific knowledge. Despite this, the construction of an intermedical field may contribute to ethnic affirmation and improve access to health. In fact, the intermedical field begins with a group of forces that are, in principle, asymmetric but that create a counter-force of resistance to power and hegemonic ideology.

Categorization of both traditional and new plants in the urban system is a key point, given that this definition is not necessarily explained by biogeographical origin, but rather implies verification of a resource that has been used in a (traditional) society for several generations, and is different from the recently introduced or new plant (Ladio \& Molares, 2013). There are many examples of Latin American literature that mention plants of Eurasian origin which have been assimilated by traditional medical systems, where they are named in the native languages and used as part of the basic therapies known for hundreds of years (Citarella et al. 1995). There are other cases, for example plants of African origin, which keep their original names even when they have been transported to other continents, such as Brazil (Albuquerque 2012; Voeks 1990, 1993). There are, therefore, different forces in play in each of these situations. In addition, as regards the coexistence of symbolic universes, syncretic religious practices such as the Andean santeria, the Haitian voodoo and the Brazilian candomblé (Albuquerque 2012; Richeri et al. 2010b; Voeks 1990) highlight the importance of these processes which have been at work for centuries.

Continuing to break down this concept to give it a more ordered character, we can say that the hybridization processes have tangible components (in this case medicinal plants and practices, Table 1) and intangible ones (values, norms, rules specific to each particular cosmovision) that determine the movement of medicinal plants-in other words, their introduction into the system, their withdrawal, exclusion or subordination. Up to the present time ethnobotanical research in urban areas has been principally dedicated to the study of the tangible components (Table 1, $\mathbf{1}$ to $\mathbf{6}$ ), and very little to the intangible ones, with few exceptions (Table 1.7; e.g. Albuquerque et al. 2007; Richeri et al. 2010b). This fact should be considered in the future, since exploring the symbolism makes it possible to unravel, from the peoples' point of view, the entire set of natural and spiritual elements that play a role in processes of illness and health, and which determine where, when, with whom, and which resource is used for treatment in a city. 


\section{CONCLUSIONS}

Research on the use of biological resources in urban systems is complex, but the concept of hybridization can be extremely useful, since the contradictions between modern and traditional elements can be reconciled. Traditional ideas are often converted into traditional-modern when the resource begins to be commercialized, and new hybrid practices are generated as a result of the simultaneous coexistence of different symbolic subsystems, thus guaranteeing the existence of conventional ideas in the midst of modern economic and cultural conditions. In this work, this concept has been applied to the use of medicinal plants in cities, but there is no doubt that its explanatory potential could be translated to other use categories and ethnobiological contexts.

This concept enables us to change the way we look at the paradigm that links, unequivocally, globalization with cultural erosion as a general pattern (McMillen 2012; Vandebroek and Balick 2012), and where the orthodox idea predominates that modernity inevitably implies the disappearance of pre-modern traditions (sensu Garcia Canclini 2001). Various studies have shown that cities are relicts of specific herbal customs, which exist alongside cosmopolitan plants of widespread use (Ceuterick et al. 2008, 2011; Pochettino et al. 2012; Richeri et al. 2010b). In other words, many cities can be seen as resistance sites of traditional herb knowledge. In particular, the so-called traditional markets or fairs act as resistance sites, even for the 'intangible' components. Hybridization, a process of intersection and transaction, is exactly what makes it possible in the cities for multiculturalism to avoid the problem of segregation and become interculturalism. Following Garcia Canclini (2001) line for this case, the danger now with respect to the maintenance of traditional resource use is not that they become transformed or readapted and interact with modern symbolic systems-in other words, that they hybridize due to an overlap of economic and cultural factors, but rather that they are excluded from this process of re-adaptation.

The premise of re-adaptation of traditional systems in changing situations has been observed mainly in rural scenarios, by diverse authors (see
Albuquerque 2013); however, in studies of urban systems, their scope has been limited (Pochettino et al. 2012; Richeri et al. 2010b; Volpato et al. 2009). The concept of the hybridization process and its sub processes includes quali-quantitative aspects that can be studied in a concrete way in cities, and given consideration to, in recognition of their role in the adaptation and re-adaptation process.

As ethnobiologists we have an important task to perform in giving birth to new visions from alternative, Latin American perspectives, and in interpreting the use of biological resources in this changing world which is becoming concentrated in urban enclaves. A world with ever increasing hybridization activity should be thought of not as a set of uniform, compact, and radically different units, but rather as having a high level of porosity and intersections, where transitory transactions are in play, and as well as this, why not, many contradictions.

\section{ACKNOWLEDGEMENTS}

This paper is a contribution of the REBISA network of Research in Biodiversity and Local Knowledge. Ana Ladio thanks the organizers of ATE for their support and for the invitation to the meeting which gave rise to this work. She also thanks CONICET (PIP 0337), FONCYT (PICT-20121028), and the many assistants whose comments have enriched this work.

\section{REFERENCES}

1. Acosta M, Vignale ND, Ladio AH (2013) Uso y comercialización de especies medicinales en la ciudad de San Salvador de Jujuy. Agrarias. Revista Científica de la Facultad de Ciencias Agrarias Universidad Nacional de Jujuy VII:74-83

2. Albuquerque UP, Andrade LHC, Silva ACO (2005) Use of plant resources in a seasonal dry forest (Northeastern Brazil). Acta Botanica Brasilica 19:27-38

3. Albuquerque UP (2012) O Dono do Segredo - o Uso de Plantas nos Cultos Afro-Brasileiros. NUPPEA, Recife

4. Albuquerque UP (2013) Etnobiologia. Bases Ecológicas e Evolutivas. 1a. ed. NUPPEA, Recife

5. Albuquerque UP, Monteiro JM, Ramos MA, Amorim ELC (2007) Medicinal and magic plants from a public market in northeastern Brazil. Journal of Ethnopharmacology 110:76-91 
6. Albuquerque UP, Cunha, LVFC, Lucena RFP, Alves RRNA (2014) Methods and Techniques in Ethnobiology and Ethnoecology. Springer, New York, NY

7. Alves RRN, Rosa XIL (2012) Animals in Traditional Folk Medicine: Implications for Conservation. Springer, New York, NY

8. Alves RRN, Rosa IL (2005) Why study the use of animal products in traditional medicines? Journal of Ethnobiology and Ethnomedicine 1:5

9. Andrade JN, Costa-neto EM (2006) 0 comércio de produtos zooterápicos na cidade de Feira de Santana, Bahia, Brasil. Sitientibus série Ciências Biológicas 6:37-43

10. Arenas PM (2007) Suplementos dietéticos : estudio etnobotánico en zonas urbanas. Kurtziana 33:193-202

11. Arenas PM (2009) Etnoficologia Aplicada. CYTED, San Salvador de Jujuy

12. Arenas PM, Cristina I, Puentes J, Buet Costantino F, Hurrell JA, Pochettino ML (2011) Adaptógenos: plantas medicinales tradicinales comercializadas como suplementos dietéticos en la conurbación Buenos Aires-La Plata (Argentina). Bondplandia 20:251-264

13. Arenas PM, Molares S, Aguilar Contreras A, Doumecq B, Gabrielli F (2013) Ethnobotanical, micrographic and pharmacological features of plant-based weight-loss products sold in naturist stores in Mexico City: the need for better quality control. Acta Botanica Brasilica 27:560-579

14. Balick M, Kronenberg F, Ososki A (2000) Medicinal plants used by Latino healers for women's health conditions in New York City. Economic Botany 54:344-357

15. Barreiro G (2006) Árboles de la Ciudad de Buenos Aires. Vazquez Mazzini Editores, Buenos Aires

16. Berlin B (1992) Ethnobiological classification: principles of categorization of plants and animals in traditional societies. Princeton University Press, Princeton

17. Bussmann RW, Sharon D, Vandebroek I, Jones A, Revene Z (2007) Health for sale: the medicinal plant markets in Trujillo and Chiclayo, Northern Peru. Journal of Ethnobiology and eEthnomedicine 3:371

18. Casagrande DG (2002) Human taste and cognition in Tzeltal Maya medicinal plants use. Journal of Ecological Anthropology 4:57-69

19. Ceuterick M, Vandebroek I, Pieroni A (2011) Resilience of Andean urban ethnobotanies: a comparison of medicinal plant use among Bolivian and Peruvian migrants in the United Kingdom and in their countries of origin. Journal of Ethnopharmacology 136:27-54

20. Ceuterick M, Vandebroek I, Torry B, Pieroni A (2008) Crosscultural adaptation in urban ethnobotany: the Colombian folk pharmacopoeia in London. Journal of Ethnopharmacology 120:342-59

21. Citarella L, Conejeros AM, Espinossa B, Jelves I, Oyarse AM, Vidal A (1995) Medicinas y Culturas en la Araucania. Editorial Sudamericana, Santiago

22. CostaNeto EM, Santos Fita D, Vargas-clavijo M (2009) Manual de Etnozoología. 1 edicion ed. Tundra Edicones, Valencia

23. Cuassolo $F$ (2009) Estudio Etnobotánico de las plantas medicinales nativas y exóticas comercializadas en la Ciudad de Bariloche, Patagonia, Argentina. Universidad Nacional del Comahue.
24. Cuassolo F, Ladio AH, Ezcurra C (2011) Aspectos de la comercialización y control de calidad de las plantas medicinales más vendidas en una comunidad urbana del NO de la Patagonia Argentina [Aspects. Boletín Latinoamericano y del Caribe de Plantas Medicinales y Aromáticas 9:166-176

25. Drescher A, Holmer R, laquinta D (2006) Urban homegardens and allotment gardens for sustainable livelihoods: Management strategies and institutional environments. Tropical Homegardens 317-338

26. Duarte Almada E (2010) Sociobiodiversidade Urbana: por uma etnoecologia das cidades. In: Silva VA, Almeida ALS, Albuquerque UP (eds) Etnobiologia e Etnoecologia. 1a. ed. NUPPEA, Recife, pp. 39-63

27. Garcia Canclini N (2001) Culturas Hibridas. Grijalbo, México

28. Hilgert NI, Higuera M de L, Kristensen MJ (2010) La medicina herbolaria en el contexto urbano. Estudio de caso en un barrio de la ciudad de Tandil, Argentina. Boletín Latinoamericano y del Caribe de Plantas Medicinales y Aromáticas 9:177190

29. Hurrell J, Costantino FB, Puentes J (2011) Huertos familiares periurbanos de las costas de Ensenada, Berisso y de la Isla Martín García(Buenos Aires, Argentina). Bonplandia 20:213230

30. Hurrell JA, Pochettino ML, Puentes J, Arenas PM (2013) Del marco tradicional al escenario urbano- Plantas ancestrales devenidas suplementos dietéticos en la conurbación Buenos Aires-La Plata,Argentina. Boletin Latinoamericano y del Caribe de Plantas Medicinales y Aromáticas 12:499-515

31. Jiang S, Quave CL (2013) A comparison of traditional food and health strategies among Taiwanese and Chinese immigrants in Atlanta, Georgia, USA. Journal of Ethnobiology and Ethnomedicine 9:61

32. Ladio A, Molares S (2014) The Dynamics of Use of Nontraditional Ethnobiological Products: Some Aspects of Study. In: Albuquerque UP, Cunha, LVFC, Lucena, RFP, Alves RRNA (eds) Methods and Techniques in Ethnobiology and Ethnoecology. Springer New York, New York, NY, pp. 311-320

33. Ladio A, Morales S, Ochoa J, Cardoso B (2013) Etnobotánica aplicada en Patagonia: la comercialización de malezas de uso comestible y medicinal en una feria urbana de San Carlos de Bariloche (Río Negro). Boletin Latinoamericano y del Caribe de Plantas Medicinales y Aromáticas 12:24-37

34. Ladio AH, Lozada $M$ (2001) Non-timber forest product use in two human populations from NW Patagonia: A quantitative approach. Human Ecology 29:367-380

35. Ladio AH, Rapoport EH (1999) El uso de plantas silvestres comestibles en una población suburbana del noroeste de la Patagonia. Parodiana 11:49-62

36. Leitão F, Leitão SG, Almeida MZ, Cantos J, Coelho T, Silva PEA (2013) Medicinal plants from open-air markets in the State of Rio de Janeiro, Brazil as a potential source of new antimycobacterial agents. Journal of Ethnopharmacology 149:513-21

37. Macía M, García E, Vidaurre $P$ (2005) An ethnobotanical survey of medicinal plants commercialized in the markets of La Paz and El Alto, Bolivia. Journal of Ethnopharmacology 97:337-50

38. Martínez GJ (2005) Recolección y Comercializaci ó n de Plantas Medicinales en el Departamento Santa María , Provincia de Córdoba , Argentina. Acta Farmaceutica Bonaerense 24:575-584

39. Martínez MR, Pochettino ML, Crivos M, Remorini C, Sy A (2006) Gathering and circulation of medicinal plants in a pluricultural 
context (Misiones, Argentina). Proceedings IVth International Congress of Ethnobotany, Istambul, Turkey. pp 107-114

40. McMillen H (2012) Ethnobotanical Knowledge Transmission and Evolution: The Case of Medicinal Markets in Tanga, Tanzania. Economic Botany 66:121-131

41. Medeiros PM, Ladio AH, Albuquerque UP (2013) Patterns of medicinal plant use by inhabitants of Brazilian urban and rural areas: a macroscale investigation based on available literature. Journal of Ethnopharmacology 150:729-46

42. Medeiros PM, Ladio AH, Albuquerque UP (2013) Critérios locais de seleção e uso diferencial de plantas medicinais : porque nós escolhemos o que escolhemos? Etnobiologia. Bases Ecológicas e Evolutivas. NUPPEA, Recife, pp. 147-165

43. Medeiros PM , Soldati GT, Alencar NL, Vandebroek I, Pieroni A, Hanazaki N, Albuquerque UP (2012) The Use of Medicinal Plants by Migrant People: Adaptation Maintenance, and Replacement. Evidence-Based Complementary and Alternative Medicine 2012:11

44. Molares S, Arenas PM, Aguilar A (2012) Etnobotánica urbana de los productos vegetales adelgazantes comercializados en México DF. Boletin Latinoamericano y del Caribe de Plantas Medicinales y Aromáticas 11:400-412

45. Nascimento JE, Lacerda EU, Nascimento VT, Melo JG, Alves BS, Silva LGM, Ramos MA, Lima CSA, Albuquerque UP, Amorin EL (2005) Produtos à base de Plantas Medicinais comercializados em Pernambuco - Nordeste do Brasil. Acta Farmaceutica Bonaerense 24:113-122

46. Pieroni A, Nebel S, Quave C, Münz $H$, Heinrich M (2002) Ethnopharmacology of liakra: traditional weedy vegetables of the Arbëreshë of the Vulture area in southern Italy. Journal of Ethnopharmacology 81:165-85

47. Pieroni A, Quave CL, Giusti ME, Papp N (2012) "We Are Italians!": The Hybrid Ethnobotany of a Venetian Diaspora in Eastern Romania. Human Ecology 40:435-451

48. Pieroni A, Sheikh Q, Ali W, Torry B (2008) Traditional medicines used by Pakistani migrants from Mirpur living in Bradford, Northern England. Complementary Therapies in Medicine 16:81-6

49. Pirondo A, Coulleri JP, Keller HA, Ferrucci MS (2011) Influencia de factores externos sobre la comercialización de plantas medicinales en un medio urbano: el caso de vendedores criollos e indígenas en Corrientes, Argentina. Boletin Latinoamericano y del Caribe de Plantas Medicinales y Aromáticas 10:553-569

50. Pochettino ML, Arenas PM, Sanchez D, Correa R (2008) Conocimiento botánico tradicional, circulación comercial y consumo de plantas medicinales en un área urbana de Argentina. Boletín Latinoamericano y del Caribe de Plantas Medicinales y Aromáticas 7:141-148

51. Pochettino ML, Ladio AH, Arenas PM (2010) Traditions and Transformations in Ethnobotany. CYTED, San Salvador de Jujuy

52. Pochettino ML, Puentes J, F.B. C, Arenas PM, Ulibarri E, Hurrell $J(2012)$ Functional Foods and Nutraceuticals in aMarket of Bolivian Immigrants in Buenos Aires (Argentina). Evidencebased Complementary and Alternative Medicine Vol. 2012, Article ID 320193.

53. Richeri M, Beeskow A, Ladio A (2010a) Las plantas y la salud en la comunidad boliviana de Puerto Madryn (Argentina). In: Pochettino ML, Ladio AH, Arenas PM (eds) Traditions and transformations in Ethnobotany. CYTED, San Salvador de Jujuy, pp. 297-302
54. Richeri M, Ladio A, Beeskow A (2010b) Etnoecología en la Patagonia árida: la adaptación de la herbolaria de una comunidad inmigrante boliviana a un nuevo contexto ambiental. In: Alves AGC, Souto FJB, Peroni N (eds) Etnoecologia em Perspectiva: Natureza, Cultura e Conservação. NUPPEA, Recife, pp. 203-227

55. Rovere AE, Molares S, Ladio AH (2013) Plantas utilizadas en cercos vivos de ciudades patagónicas: aportes de la etnobotánica para la conservación. Ecología Austral 23:165173

56. Soldati GT, Albuquerque UP (2012) Ethnobotany in Intermedical Spaces: The Case of the Fulni-ô Indians (Northeastern Brazil). Evidence-Based Complementary and Alternative Medicine vol. 2012, Article ID 648469,

57. Vandebroek I, Balick MJ (2012) Globalization and loss of plant knowledge: challenging the paradigm. PloS one 2012, 7:e37643

58. Voeks R (1990) Sacred Leaves of Brazilian Candomble. Geographical Review 80:118-131

59. Voeks R (1993) African medicine and magic in the Americas. Geographical Review 83:66-78

60. Volpato G, Godínez D, Beyra Á (2009) Migration and ethnobotanical practices: the case of tifey among Haitian immigrants in Cuba. Human Ecology 37:43-53

61. Waldstein A (2006) Mexican migrant ethnopharmacology: pharmacopoeia, classification of medicines and explanations of efficacy. Journal of Ethnopharmacology 108:299-310

62. WinklerPrins A (2002) House-lot gardens in Santarém, Pará, Brazil: Linking rural with urban. Urban Ecosystems 6:43-65

63. Zapata J, Shippee-Rice R (1999) The Use of Folk Healing and Healers by Six Latinos living in New England. Journal of Transcultural Nursing 10:136-142

Received: 01 July 2014

Accepted: 02 October 2014

Published: 07 November 2014 